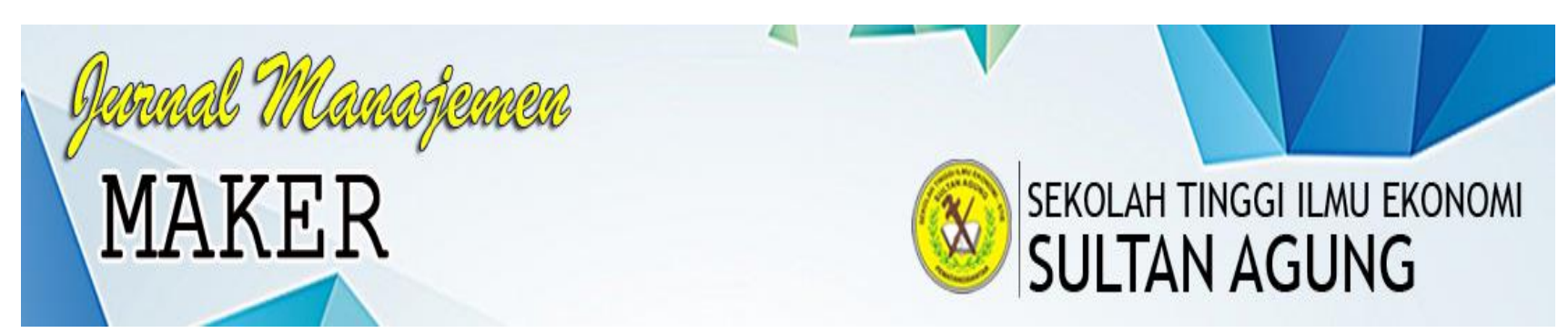

\title{
PENGARUH KOMITMEN TERHADAP KIINERJA PEGWAI DENGAN DISIPLIN KERJA SEBAGAI VARIABEL INTERVENING PADA KANTOR KECAMATAN SIANTAR KABUPATEN SIMALUNGUN
}

\author{
Oleh: \\ Bagus Habi Wahyu \\ S1 Manajemen \\ Darwin Lie, Efendi, Sudung Simatupang
}

\begin{abstract}
Abstrak
Hasil penelitian dapat disimpulkan sebagai berikut: 1. Komitmen, disiplin kerja, dan kinerja pegawai cukup baik. 2. Terdapat pengaruh yang positif dan signifikan antara komitmen terhadap disiplin kerja. Terdapat pengaruh yang positif dan signifikan antara disiplin kerja terhadap kinerja. 3. Terdapat hubungan yang kuat dan positif antara komitmen terhadap disiplin kerja. Terdapat hubungan yang kuat dan positif antara disiplin kerja terhadap kinerja pegawai. 4. Hasil hipotesis $\mathrm{H}_{0}$ ditolak, artinya komitmen berpengaruh positif dan signifikan terhadap kinerja pegawai dengan disiplin kerja sebagai variabel intervening.
\end{abstract}

Kata Kunci: Kompensasi, Fasilitas, dan Kepuasan Kerja Pegawai

\section{Abstract}

Research results can be summed up as follows: 1. The quality of Commitmen of Employee is quite good, Work Discipline is good, and Employee Performance was quite satisfied. 2. There is a positive influence between commitmen toward against work disciplin. There is a positive influence between Work Discipline against Employee Performance. 3. There is moderately high and positive correlation between Commitmen of Employee against a Work Discipline. means there is a high and positive correlation between Work Discipline with employee performance. 4. The results of the hypothesis $\mathrm{HO}$ is rejected, meaning that Commitmen of employee have a positive and significant impact on Employee performance through Work Discipline as Intervening Variables.

\section{Keywords: Compensation, Facilities, and Job Satisfaction}

\section{A. PENDAHULUAN}

\section{Latar Belakang Masalah}

Keberhasilan manajemen sumber daya manusia merupakan saranan penting dalam meningkatkan kinerja dan hasil organisasi, dalam mewujudkan pegawai yang memiliki disiplin, komitmen dan kinerja yang tinggi. Maka dari itu Sumber daya manusia atau tenaga kerja sangat diperlukan baik di usaha-usaha sosial, perusahaan-perusahaan, atau pada instansi pemerintah pusat maupun daerah, khususnya pada kantor kecamatan siantar simalungun.

Kantor Kecamatan Siantar Kab. Simalungun merupakan instansi pemerintahan yang bertugas berdasarkan azas otonomi dan tugas pembantuan serta tugas-tugas lain yang diberikan Bupati yang berhubungan dengan pemerintahan. Sebagai instansi pemerintah daerah dalam bidang pemerintahan dan memberikan pelayanan bagi masyarakat maka sangat dibutuhkan peranan seorang pemimpin yang mampu menjalankan organisasi demi pemenuhan kebutuhan masyarakat yang beragam dan kemajuan didaerah Kabupaten Simalungun.

Kinerja pegawai pada instansi pemerintahan di Kantor Kecamatan Siantar Simalungun diukur dari dimensi bedasarkan Sasaran Kerja Pegawai (SKP) dan perilaku kerja (PK). Berikut ini adalah kinerja 35 pegawai negeri sipil pada Kantor Kecamatan Siantar Simalungun. 
Tabel 1

Dimensi Kinerja Pegawai pada Kantor Kecamatan Siantar Simalungun

\begin{tabular}{|c|c|c|c|c|c|c|}
\hline Dimensi Kinerja & $\begin{array}{l}\mathbf{S} \\
\mathbf{B}\end{array}$ & $\mathbf{B}$ & $\begin{array}{l}\text { C } \\
\text { B }\end{array}$ & $\begin{array}{l}\mathbf{T} \\
\mathbf{B}\end{array}$ & $\begin{array}{l}\text { S } \\
\mathbf{T} \\
\mathbf{B}\end{array}$ & $\begin{array}{c}\text { Ju } \\
\text { mla } \\
\text { h }\end{array}$ \\
\hline $\begin{array}{c}\text { Sasaran Kerja } \\
\text { Pegawai }\end{array}$ & $\begin{array}{l}30 \\
\%\end{array}$ & $\begin{array}{l}50 \\
\%\end{array}$ & $\begin{array}{l}15 \\
\%\end{array}$ & $\begin{array}{l}5 \\
\%\end{array}$ & $\mathbf{0}$ & $\begin{array}{c}100 \\
\%\end{array}$ \\
\hline Perilaku Kerja & $\begin{array}{l}30 \\
\%\end{array}$ & $\begin{array}{l}40 \\
\%\end{array}$ & $\begin{array}{l}25 \\
\%\end{array}$ & $\begin{array}{l}5 \\
\%\end{array}$ & $\mathbf{0}$ & $\begin{array}{c}100 \\
\%\end{array}$ \\
\hline Rata-rata & $\begin{array}{l}30 \\
\%\end{array}$ & $\begin{array}{l}45 \\
\%\end{array}$ & $\begin{array}{l}20 \\
\%\end{array}$ & $\begin{array}{l}5 \\
\%\end{array}$ & $\mathbf{0}$ & $\begin{array}{c}100 \\
\%\end{array}$ \\
\hline
\end{tabular}

Sumber: hasil wawancara pada Kasubag. Umum dan Kepegawaian (April 2018)

Pada tabel 1 di atas dapat diketahui bahwa seluruh dimensi kinerja pegawai pada Kantor Kecamatan Siantar Kab. Simalungun masih belum optimal. Hal ini dapat dilihat dari beberapa dimensi masih ada katagori cukup baik dengan rata-rata sebesar $20 \%$ dan tidak baik dengan persentase rata-rata sebesar 5\%. Pada dimensi sasaran kerja pegawai cukup baik menunjukkan pimpinan kurang memperhatikan pegawai dalam menyelesaikan pekerjaannya, dimana masih terdapat pegawai yang tidak menguasai tugas yang diberikan. Ada pegawai yang jumlah pekerjannya lebih banyak dan ada pegawai yang pekerjanya sedikit sehingga yang pekerjaannya lebih banyak tidak menyelesaikannya dengan optimal.

Sedangkan pada dimensi perilaku kerja belum optimal karena kurangnya orientasi pelayanan pegawai pada masyarakat dimana tidak ada kejelasan waktu yang diperluka dalam menyelesaikan persoalan-persoalan pelayanan yang disebabkan pimpinan atau pegawai yang bertugas sedang tidak ditempat saat masyarakat datang dan juga kurang optimal kerjasama antara pegawai. Hal ini disebabkan karena pegawai lebih mementingkan kegiatan ataupun pekerjaan masing-masing.

Menurut Rivai (2009:598), "mengatakan bahwa semangkin baik disiplin karyawan pada sebuah perusahaan, semangkin tinggi prestasi kerja yang dapat dicapai". Dimensi disiplin kerja yang diterapkan adalah menjalankan kewajiban dan manjauhi larangan.

Adapun fenomena pada dimensi menjalankan kewajiban masih terdapat pegawai kurang bertanggung jawab melaksanakan tugas kedinasan seperti tidak mengikuti rapat, tidak melaporkan hasil kinerja dilapangan pada atasan. Ada pegawai tidak menaati ketentuan jam kerja seperti datang terlambat dan pulang lebih awal. Kurang membimbing pegawai baru dalam melaksanakan tugas. Sedangkan pada dimensi menjauhi larangan belum optimal. Hal ini dapat dilihat bahwa terlibat dalam kegiatan kampanye untuk mendukung calon Kepala Daerah dan Wakil Kepala Daerah.

Sutrisno (2010:296), “yang menyatakan bahwa pegawai itu merupakan hal yang penting bagi organisasi, terutama untuk menjaga kelangsungan. Untuk mewujudkan tujuan organisasi diperlukan pegawai dengan komitmen yang tinggi”. Komitmen yang ada pada Kantor Kecamatan Siantar Simalungun meliputi komitmen afektif, komitmen berkelanjuan dan komitmen normatif.

Pada dimensi komitmen berkelanjutan, pegawai berkeinginan untuk tetap bekerja pada organisai karena membutuhkan pekerjaan tersebut. Fenomena komitmen yang belum optimal pada Kantor Kecamatan Siantar Kab. Simalungun terjadi pada dimensi afektif, dimana masih terdapat pegawai yang kurang melibatkan dirinya terhadap pencapaian tujuan organisasi dan fenomena dimensi normatif, dimana masih terdapat pegawai yang melakukan pekerjaan diluar organisasi.

Dari fenomena lapangan maka dapat ditemukan masalah yang terdapat dilapangan yaitu kurangnya disiplin pada pegawai sehingga mengakibatkan komitmen pada pegawai juga kurang oleh sebab itu kinerja pegawai ikut menurun. Maka dari uraian di atas dapat dilihat adanya masalah antara fenomena dengan harapan, sehingga penulis tertarik melakukan penelitian.

\section{Rumusan Masalah}

a. Bagaimana gambaran disiplin kerja, komitmen dan kinerja Pegawai pada Kantor Kecamatan Siantar Kab. Simalungun.

b. Bagaimana pengaruh komitmen terhadap disiplin kerja pada Kantor Kecamatan Siantar Kab. Simalungun. 
c. Bagaimana pengaruh disiplin kerja terhadap kinerja pegawai pada Kantor Kecamatan Siantar Kab. Simalungun.

\section{Tujuan Penelitian}

a. Untuk mengetahui gambaran komitmen, disiplin kerja dan kinerja pegawai pada Kantor Kecamatan Siantar Kab. Simalungun.

b. Untuk mengetahui pengaruh komitmen terhadap disiplin kerja pada Kantor Kecamatan Siantar Kab. Simalungun.

c. Untuk mengetahui pengaruh disiplin kerja terhadap kinerja pegawai pada Kantor Kecamatan Siantar Kab. Simalungun.

\section{Metode Penelitian}

Tempat penelitian dilakukan pada Kantor Kecamatan Siantar yang beralamat Jln. Asahan Km. 4,5 Kabupaten Simalungun Provinsi Sumatra Utara. Populasi penelitian seluruh Pegawai Negeri Sipil (PNS) pada Kantor Kecamatan Siantary ang berjumlah 40 orang pegawai dan seluruhnya dijadikan sebagai sampel.

Desain penelitian adalah Penelitian Kepustakaan (Library Reseacrh) dan Penelitian lapangan (Field Research). Teknik pengumpulan data berupa Kuesioner, Wawancara, dan Dokumentasi.Jenis data yang digunakan dalam penelitian ini yaitu data kualitatif dan kuantitatif. Hasil data yang diperoleh dari lapangan akan dianalisis secara deskriptif baik bersifat kualitatif dan kuantitatif.

\section{B. LANDASAN TEORI}

\section{Manajemen}

Untuk mencapai tujuan organisasi yang baik, perusahaan atau organisasi harus memiliki manajemen yang baik. Manajemen dikatakan baik apabila mampu mengatur orang-orang di dalam perusahaan untuk dapat bekerja secara lebih baik sehingga tujuan perusahaan dapat tercapai.

$\begin{array}{ccc}\text { Menurut } & \text { Handoko } & (2003: 8), \\ \text { manajemen ialah "suatu } & \text { proses }\end{array}$
perencanaan, pengorganisasian, pengarahan dan pengendalian serta pengawasan kegiatan organisasi dan penggunaan sumber daya manusia lainnya agar tercapai tujuan organisasi”. Menurut Robbins dan Mary (2010:7), "manajemen adalah aktivitas kerja yang melibatkan koordinasi dan pengawasan terhadap pekerjaan orang lain, sehingga pekerjaan tersebut dapat diselesaikan secara efisien dan afektif'.

Sedangkan Menurut Daft (2002:8), manajemen ialah "pencapaian tujuan organisasi dengan cara yang efektif melalui perencanaan, pengorganisasian, pengarahan dan pengendalian sumber daya organisasi”. Berdasarkan definisi para ahli, disimpulkan bahwa manajemen adalah suatu proses untuk mencapai tujuan dengan cara yang efektif melalui perencanaan, pengorganisasian, pengarahan dan pengendalian sumber daya organisasi.

\section{Manajemen Sumber} Manusia

Dalam suatu organisasi, manajemen sumber daya manusia memiliki peran penting dalam mencapai tujuannya. Tanpa adanya sumber daya manusia operasional suatu organisasi tidak dapat berjalan dengan lancar. Menurut Mathis dan John (2006:3), "manajemen sumber daya manusia adalah rancangan sistem-sistem formal dalam sebuah organisasi untuk memastikan penggunaan, bakat manusia secara efektif dan efisian guna mencapai tujuan organisasional". Menurut Dessler (2006:4) memberikan pengertian "manajemen sumber daya manusia adalah proses memperoleh, melatih, menilai dan memberikan kompensasi kepada karyawan, memperhatikan hubungan kerja mereka, kesehatan keamanan dan masalah keadilan". Menurut Sutrisno

(2010:7), "manajemen sumber daya manusia sebagai suatu perencanaan, pengorganisasian, pengarahan dan pengawasan atas pengadaan, pengembangan, kompensasi, pengintegrasian, pemeliharaan dan pemutusan hubungan kerja dengan maksud untuk mencapai tujuan organisasi perusahaan secara terpadu". Berdasarkan pendapat para ahli, maka manajemen sumber daya manusia adalah rancangan sistem-sistem formal dalam suatu organisasi yang memiliki proses memperoleh, melatih, menilai dan memberikan kompensasi, memperhatikan hubungan kerja mereka, kesehatan keamanan dan masalah keadilan dengan maksud untuk mencapai tujuan organisasi. 


\section{Komitmen}

Dalam setiap instansi tetap membutuhkan pegawai sebagai bagian dari instansi. Namun dalam menjadi bagian dari organisasi atau ikatan dinas, maka pegawai perlu dilatih untuk memiliki komitmen. Komitmen menjadi peranan penting dalam instansi pemerintah, karyawan atau pegawai yang memiliki komitmen menjadi faktor penunjang dalam menjalankan komitmen dalam organisasi. Menurut Sutrisno (2010:296), "komitmen merupakan sikap loyalitas pekerja terhadap organisasinya dan juga merupakan suatu proses mengekspresikan perhatian dan partisipasinya terhadap organisasi". Menurut Panggabean (2004:135), "komitmen adalah kuatnya pengenalan dan keterlibatan seseorang dalam suatu organisasi tertentu". Menurut Robbins dan Mary (2010:40), "komitmen organisasi merupakan derajat di mana seorang karyawan mengidentifikasikan dirinya dengan organisasi tertentu beserta tujuannya dan berkeinginan untuk mempertahankan keanggotaannya di dalam organisasi tersebut".

Berdasarkan definisi, dapat disimpulkan bahwa komitmen adalah merupakan derajat di mana seorang pegawai mengidentifikasi dirinya dengan organisasi tertentu dan sikap loyalitas pegawai terhadap organisasinya dan melaksanakan tugas kedinasan yang dipercayakan kepada pegawai dengan penuh pengabdian, kesadaran, dan tanggung jawab, serta merupakan suatu proses mengekspresikan, keinginan dan keyakinan berdasarkan kesepakatan yang telah ditentukan.

\section{Disiplin Kerja}

Kedisiplinan merupakan salah satu fungsi operatif manajemen sumber daya manusia yang terpenting. Semakin baik disiplin karyawan pada sebuah perusahaan, semakin tinggi prestasi kerja yang dapat dicapai. Sebaliknya, tanpa disiplin karyawan yang baik sulit bagi sebuah perusahaan mencapai hasil yang optimal. Disiplin yang baik menggambarkan besarnya tanggung jawab seseorang terhadap tugas-tugas yang diberikan kepadanya. Hal ini mendorong keinginan untuk kerja, semangat kerja, dan terwujudnya tujuan perusahaan, karyawan, serta masyarakat pada umumnya. Bedasarkan Peraturan Pemerintah RI Nomor 53 Tahun 2010 Tentang Disiplin PNS yang berpendapat mengenai disiplin kerja ialah "kesanggupan Pegawai Negeri Sipil untuk menaati kewajiban dan menghindari larangan yang ditentukan dalam peraturan perundang-undangan dan peraturan kedinasan yang apabila tidak ditaati atau dilanggar dijatuhi hukuman disiplin".

Kemudian menurut Sutrisno (2010:86), disipiln adalah: "sikap kesediaan dan kerelaan seseorang untuk mematuhi dan mentaati norma-norma peraturan yang berlaku disekitarnya. Sedangkan menurut Rivai (2009:599), disiplin kerja adalah: "suatu alat yang digunakan para manajer untuk berkomunikasi dengan karyawan agar mereka bersedia untuk mengubah suatu perilaku serta sebagai suatu upaya untuk meningkatkan kesadaran dan/atau kesediaan seseorang mentaati semua peraturan perusahaan dan norma-norma sosial yang berlaku."

Berdasarkan pendapat ahli diatas, dapat disimpulkan bahwa disiplin kerja adalah suatu alat yang digunakan para manejer untuk berkomunikasi dengan pegawai agar mereka bersedia untuk mengubah suatu perilaku, serta kesanggupan pegawai untuk menaati kewajiban dan menghindar dari larangan. Ditentukan dalam peraturan yang telah ditetapkan sebagai suatu upaya untuk meningkatkan kesadaran dan kesediaan pegawai untuk mentaati semua peraturan yang telah ditetapkan.

\section{Kinerja}

Kinerja merupakan istilah yang berasal dari kata Job Performance atau Actual Perfomance yaitu kinerja atau prestasi sesungguhnya yang dicapai. Penilaian kinerja pada dasarnya adalah penilaian terhadap semua kegiatan individu dalam mencapai tujuan organisasi. Menurut Dessler (2007:87), "kinerja adalah prestasi aktual karyawan atau pegawai". Menurut Sedarmayanti (2007:87), "kinerja merupakan prestasi kerja, hasil kerja, 
pelaksana kinerja atau untuk kerja". Sedangkan menurut Mathis dan John (2006:113), "kinerja adalah suatu hasil kerja yang dicapai seseorang dalam melaksanakan tugas-tugas yang dibebankan kepadanya yang disarankan atas pengalaman, kecakapan, kesungguhan serta waktu".

Dari pendapat ahli di atas, dapat ditarik kesimpulan bahwa kinerja pegawai adalah suatu hasil kerja yang dicapai seorang pegawai dalam melaksanakan tugas-tugas dibebankan kepadanya yang dimana hasil kerja yang dicapai pegawai diukur berdasarkan aturan yang telah ditetapkan sesuai dengan sasaran kerja dan perilaku kerja pegawai demi mencapai tujuan yang efektif dan efisien.

\section{PEMBAHASAN}

\section{Analisis}

\section{a. Deskriptif Kualitatif}

Analisis deskriptif Analisis deskriptif dimaksudkan untuk mendapatkan gambaran komitmen, disiplin kerja dan kinerja pegawai pada kantor kecamatan Siantar. Setelah pengujian data maka langkah selanjutnya melakukan pengkajian kualitatif sebagai gambaran fenomena dari variabel penelitian pada saat sekarang ini.

Adapun penetapan kriteria nilai ratarata jawaban dari responden tersebut dimasukkan kedalam kelas-kelas interval dimana penentuan intervalnya memakai rumus sebagai berikut:

Tabel 2

Nilai Interval dan Kategori Jawaban Responden

\begin{tabular}{|c|c|c|c|}
\hline \multirow{3}{*}{$\begin{array}{c}\text { Nilai } \\
\text { Interva } \\
\mathbf{l}\end{array}$} & \multirow{2}{*}{\multicolumn{3}{|c|}{ Kategori }} \\
\hline & & & \\
\hline & $\begin{array}{c}\text { Kompen } \\
\text { sasi }\end{array}$ & Fasilitas & $\begin{array}{c}\text { Kepuasan } \\
\text { Kerja } \\
\text { Pegawai } \\
\end{array}$ \\
\hline $\begin{array}{c}1,00- \\
1,80\end{array}$ & $\begin{array}{c}\text { Sangat } \\
\text { Tidak } \\
\text { Baik }\end{array}$ & $\begin{array}{c}\text { Sangat } \\
\text { Tidak Baik }\end{array}$ & $\begin{array}{c}\text { Sangat } \\
\text { Tidak Baik }\end{array}$ \\
\hline $\begin{array}{c}1,81- \\
2,60\end{array}$ & $\begin{array}{l}\text { Tidak } \\
\text { Baik }\end{array}$ & Tidak Baik & Tidak Baik \\
\hline $\begin{array}{c}2,61- \\
3,40\end{array}$ & $\begin{array}{l}\text { Cukup } \\
\text { Baik }\end{array}$ & $\begin{array}{c}\text { Cukup } \\
\text { Baik }\end{array}$ & Cukup Baik \\
\hline $\begin{array}{c}3,41- \\
4,20\end{array}$ & Baik & Baik & Baik \\
\hline $\begin{array}{c}4,21- \\
5.00\end{array}$ & $\begin{array}{c}\text { Sangat } \\
\text { Baik }\end{array}$ & $\begin{array}{c}\text { Sangat } \\
\text { Baik }\end{array}$ & Sangat Baik \\
\hline
\end{tabular}

Sumber: hasil pengolahan data (2018)

\section{1) Gambaran Komitmen Pada Kantor Kecamatan Siantar Kab. Simalungun}

Dari tabel 2 di atas dapat dilihat pada dimensi komitmen afektif pada indikator tetap bertahan di organisasi yang merupakan kebutuhan pegawai diperoleh nilai rata-rata sebesar 3,20 dengan kriteria jawaban cukub baik, ini disebabkan pegawai merasa senang dengan suasana kerja yang tercipta dalam instansi sehingga membuat pegawai merasa nyaman bekerja. Indikator kondisi dengan rekan kerja berada pada rata-rata 3,27 dengan kriteria jawaban cukup baik, hal ini direnakan pegawai merasa cukup nyaman berada pada instansi tersebut.

Indikator keterlibatan pegawai dalam merealisasikan tujuan dari instansi diperoleh nilai rata-rata sebesar 3,20 dengan kriteria jawaban cukup baik, hal ini disebabkan masih adanya pegawai yang kurang melibatkan dirinya dalam pencapaian tujuan organisasi. Selanjutnya indikator keterikatan emosional pegawai terhadap instansi diporoleh nilai rata-rata sebesar 3,22 ini dikarenakan pegawai merasa segala permasalahan yang dihadapi oleh instansi merupakan bagian dari masalah pegawai juga. Dimensi komitmen berkelanjutan dengan indikator kerugian apabila meninggalkan instansi diperoleh nilai rata-rata sebesar 2,97 dengan kriteria jawaban cukup baik, hal ini disebabkan organisasi berusaha untuk menciptakan suasana kerja yang nyaman dan menghargai setiap hasil kerja yang dicapai oleh pegawai.

Indikator untuk menghindari sangsi yang diberkan instansi diperoleh nilai ratarata sebesar 3,37 dengan kriteria jawaban cukup baik dimana pegawai berusaha untuk menghindari sangsi yang diberikan kepada pegawai agar tercapainya tujuan organisasi. Selanjutnya indikator keterikatan untuk tetap bertahan dalam instansi diperoleh nilai rata-rata sebesar 3.02 dengan kriteria jawaban cukup baik, ini dikarenakan pegawai menganggap bahwa bekerja pada instansi merupakan bagian dari kebutuhan mereka. 
Dimensi komitmen normatif dengan indikator tanggung jawab terhadap instansi diperoleh nilai rata-rata sebesar 3,27 dengan kriteria cukup baik, hal ini disebabkan instansi selalu melibatkan pegawai dalam setiap kegiatan yang diadakan oleh instansi. Kemudian indikator rasa bersalah saat meninggalkan instansi diperoleh nilai ratarata sebesar 3,12 dengan kriteria baik, ini dikarenakan pegawai merasa bahwa penghasilan yang diterima sudah sesuai dengan kinerja yang dihasilkan. Pada Indikator tetap bertahan untuk memenuhi kewajiban kerja diperoleh nilai rata-rata sebesar 3,12 dengan kriteria jawaban cukup baik, hal ini disebabkan adanya rasa tanggung jawab dalam diri pegawai untuk melaksanakan tugas-tugas yang diberikan dengan sepenuh hati. Dengan indikator keyakinan dalam mengerjakan tugas yang diberikan diperoleh nilai rata-rata 3,17 dengan kriteria cukup baik, hal ini menunjukan bahwa pegawai mengerjakaj tugas dengan keyakinan yang cukup baik dengan penuh tanggung jawab.

Secara keseluruhan dapat dilihat bahwa untuk total jawaban responden mengenai komitmen memperoleh nilai ratarata sebesar 3,16 dengan kareteria jawaban cukup baik. Nilai rata-rata tertinggi sebesar 3,47 dengan kriteria jawaban baik pada dimensi komitmen normatif dengan indikator rasa bersalah anda jika meninggalkan instansi. Sedangkan nilai rata-rata terendah sebesar 2,87 dengan kriteria cukup baik pada dimensi komitmen normatif dengan indikator rasa bersalah pegawai ketika meninggalkan instansi.

\section{2) Gambaran Disiplin pada Kantor Kecamatan Siantar}

Dari tabel 2 di atas dapat dijelaskan, untuk dimensi menjalankan kewajiban dengan indikator mengucap sumpah PNS berada pada rata-rata 2,30 pada indikator keterikatan secara emosional berada pada rata-rata 2,45 dengan kriteria jawaban tidak baik, dikarenakan adanya kesadaran pegawai dalam mengucapkan sumpah PNS sehingga pegawai dapat menjalankan tugas dan kewajibannya dengan baik sesuai dengan tugas PNS.
Indikator mengucap sumpah jabatan berada pada rata-rata 3,67 dengan kriteria jawaban baik. Hal ini disebabkan adanya kesadaran pegawai bahwa sumpah jabatan dapat membuat pegawai tidak memanfaatkan jabatannya untu hal-hal yang negatif. Indikator penerapan nilai-nilai Pancasila pada saat bekerja berada pada rata-rata 3,67 dengan kriteria jawaban baik, ini dikarenakan pancasila merupakan Dasar Negara Republik Indonesia dimana nilainilainya diterapkan dalam kehidupan seharihari.

Indikator kesadaran dalam menerapkan nilai-niai pancasila ketika bekerja berada pada rata-rata 3,67 dengan kriteria jawaban baik, hal ini menunjukkan adanya jiwa pancasila didalam sebagian diri pegawai. Pada Indikator dalam mentaati peraturan kedinasan berada pada rata-rata 2,77 dengan kriteria jawaban cukup baik, hal ini disebabkan masih ada pegawai yang kurang menaati peraturan organisasi. Indikator dalam menjunjung tinggi kehormatan berada pada rata-rata 3,37 dengan kriteri jawaban cukup baik, dikarenakan PNS merupakan abdi negara yang harus menjunjung tinggi kehormatan negara meskipun masih ada pegawai yang kurang dalam menjunjung negara.

Kemudian Indikator sikap dalam mengutamakan kepentingan negara dari pada kepentingan pribadi berada pada ratarata 3,70 dengan kriteria baik, hal ini masih ada pegawai yang lebih mementingkan hal peribadi ketimbang negara. Selanjutnya Indikator dalam memegang rahasia jabatan berada pada rata-rata 3,80 dengan kriteria jawaban baik, ini dikarenakan pegawai masih dalam kategori cukup baik dalam memegang rahasia jabatan.

Indikator sikap dalam bekerja dengan jujur berada pada rata-rata 3,60 dengan kriteria jawaban cukup baik, ini disebabkan masih ada pegawai yang menhgharapkan imbalan dalam melayani masyrakat. Indikator kemauan untuk melaporkan halhal uang dapat membahayakan negara berada pada rata-rata 3,67 dengan kriteria jawaban baik, hal ini masih ada pegawai yang cuek dalam kepenting tugas negara. 
Pada Indikator sikap dalam mentaati ketentuan jam kerja berada pada rata-rata 3.37 dengan kriteria rata-rata jawaban cukup baik, hal ini ada pegawai yang meninggalkan kantor pada saat jam kerja. Indikator usaha dalam memelihara barangbarang milik negara berada pada rata-rata 3,55 dengan kriteria jawaban baik, dimana pegawaai merawat barang milik negara cukup baik. Indikator usaha dalam memberikan pelayanan yang baik untuk masyarakat berada pada rata-rata 3.57 dengan kriteria jawaban baik karena masih ada pegawai yang tidak ikut andil dalam memberikan pelayanan kepada masyarakat. kemudian Indikator kemampuan dalam membimbing pegawai baru dalam melaksanakan tugas berada pada rata-rata 3,17 dengan kriteria cuku baik, hal ini pegawai masih digolongkan dalam kategori cukup baik dalam membimbing pegawai baru.

Pada Indikator kemauan dalam melaksanakan tugas kedinasan berada pada rata-rata 3,00 dengan kriteria jawab cukup baik, hal ini merupakan tugas dari pegawai dalam melaksanakan kewajibannya. Indikator kesadaran untuk tidak menyalah gunakan wewenang yang diberikan berada pada rata-rata 3,07 dengan kriteria jawaban cukup baik, ini dikarenakan kegiatan yang dapat memberi contoh kepada rekan-rekan pegawai lainnya. Indikator kesadaran untuk tidak menjadi perentara keuntungan pribadi berada pada rata-rata 3,02 dengan kriteria jawaban cukup baik, hal ini dikarenakan masih terdapat pegawai masih menjadi perantara keuntungan pribadi.

Pada Indikator kesadaran agar tidak bekerja untuk negara lain tanpa izin pemerintah berada pada rata-rata 3,17 dengan kriteria cukup baik, dimana pegawai mengikuti peraturan dari pemerintah. Indikator kesadaran untuk tidak bekerja dengan perusahaan asing berada pada ratarata 2,95 dengan kriteria cukup baik, hal ini karena pegawai merasa nyaman berada di ikantan kedinasan. Indikator kesadaran untuk tidak memiliki barang-barang milik negara secara tidak sah berada pada ratarata 3,22 dengan kriteria cukup baik, hal ini menunjukan adanya kesadaran pegawai untuk tidak memiliki barang-barang milik negara secara tidak sah.

Kemudian Indikator kesadara untuk tidak melakukan kegiatan bersama dengan atasan untuk kepentingan pribadi berada pada rata-rata 2,80 dengan kriteria jawaban cukup baik, bahwa pegawai sadar atas apa yang pegawai lakukan. Indikator kesadaran untuk tidak menerima hadiah yang berhubung dengan jabatan berada pada ratarata 3,15 dengan kriteria baik, karena pimpinan lebih mengutamakan kualitas pegawai yang dimiliki untuk menunjang tujuan dari organisasi.

Pada Indikator kesadaran pegawai untuk bertindak sewenang-wenang terhadap bawahan berada pada rata-rata 2,85 dengan kriteri cukup baik, hal ini menunjukan bahwa pimpinan merupakan contoh bagi pegawai lain. Indikator tindakan untuk tidak melakukan suatu tindakan yang dapat menghalangi atau mempersulit salah satu pihak yang dilayani berada pada rata-rata 2,97 dengan kriteria cukup baik hal ini bahwa pegawai bekerja memberikan pelayanan untuk masyarakat untuk mengurus keprluan dalam administrasi.

Indikator kesadaran untuk tidak menghalangi tugas kedinasan berada pada rata-rata 2,90 dengan kriteria cukup baik, hal ini pegawai memiliki kerjasama yang baik pada setiap instansi. Kemudian Indikator kesadaran untuk tidak mendukung calon peserta pemilu dengan mengunakan fasilitas negara berada pada rata-rata 2,80 denga kriteria cukup baik, hal ini bahwa pegawai diharuskan bersikap netral.

Secara keseluruhan disiplin kerja pegawai memiliki nilai rata-rata 3,27 dengan kriteria cukup baik. Nilai rata-rata disiplin kerja tertinggi adalah 3,87 dengan kriteria cukup baik pada indikator usaha pegawai untuk mencapai sasaran kerja pegawai. Nilai rata-rata terendah adalah 2,30 dengan kriteria cukup baik pada indikator pegawai dalam mengucapkan sumpah jabatan.

\section{3) Gambaran Kinerja Pegawai pada Kantor Kecamatan Siatar}

Dari tabel 2 di atas dapat diketahu dimensi sasaran kerja pegawai untuk indikator tingkat pencapaian target kerja 
memperoleh nilai rata-rata 3,05 dengan kriteria jawaban cukup baik, dikarenakan masih ada pegawai yang ikut andil dalam melaksanakan tugas yang diberikan. Indikator menangani volume pekerjaan yang cukup banyak memperoleh nilai ratarata 3,10 dengan kriteria jawaban cukup baik, hal ini dikarenakan karyawan kurang tanggung jawab ketika diberikan pekerjaan dengan menunda. Indikator Kualitas hasil kerja yang dicapai memperoleh nilai ratarata 3,17 dengan kriteria jawaban cukup baik. hal ini karena masih ada pegawai yang dapat mengunakan perlalatan eletronik kantor dengan baik.

Indikator tingkat ketelitian dalam menyelesaikan pekerjaan memperoleh nilai rata-rata 3,17 dengan kriteria jawaban cukup baik, hal ini dikarenakan adanya pegawai yang kurang peduli dengan tugas yang diberikan. pada indikator ketetapan waktu dalam menyelesaikan tugas yang diberikan memperoleh nilai rata-rata 3,45 dengan kriteria jawaban baik, hal ini dikarenakan pegawai berusaha sebaik mungkin agar tugas dapat selesai tepat waktu.

Kemudian Indikator jumlah anggaran yang diberikan dalam menyelesaikan pekerjaan memperoleh nilai rata-rata 3,62 dengan kriteria jawaban baik, hal ini dikarenakan pegawai dapat membagi anggaran untuk keperluan instansi dilakukan dengan baik. Indikator kemampuan dalam mengelolah biaya memperoleh nilai rata-rata 3,82 dengan kriteria baik, hal ini pegawai dapat mengelolah biaya dilakukan dengan baik.

Terakhir pada dimensi perilaku kerja pada indikator kuaitas pelayanan yang diberikan memperoleh nilai rata-rata 3,65 dengan kriteria jawaban baik, hal ini dikarenakan pegawai mampu mengembangangkan diri dengan kreativitas dalam melaksanakan tugas.

Indikator sikap saat memberikan pelayanan memperoleh nilai rata-rata 3,57 dengan kriteria jawaban baik, hal ini pegawai melakukan kewajiban dengan perilaku yang baik. Kemudian Indikator etika dalam beker memperoleh nilai ratarata 3,30 dengan kritera jawaban cukup baik, hal ini masih ada pegawai meninggalkan kantor sebelum waktunya.

Selanjutnya Indikator tingkat kejujuran dalam bekerja memperoleh nilai rata-rata 3,87 dengan kriteria jawaban baik, hal ini dikarenakan pegawai memjunjung tinggi kepercayaan pimpinan terhadap mereka. Indikator tanggung jawab dalam instansi memperoleh nilai rata-rata 3,65 dengan kriteria baik, hal ini pegawai memiliki rasa nyaman kepada instansi dan enggan untuk menjelekkan nama instansi.

Indikator tingkat kehadiran dalam bekerja memperoleh nilai rata-rata 3,57 dengan kriteria jawaban baik, hal ini dikarenakan kehadiran merupakan penilaian dari pemberian tambahan dari pendapatan pegawai. Pada indikator loyalitas bekerja dalam instansi memperoleh nilai rata-rata 3,17 dengan kriteria jawaban cukup baik, dikarenakan masih ada pegawai yang masih mementingkan hal peribadi ketimbang instansi.

Indikator kepatuhan dalam menaati peraturan perundang-undangan yang telah ditetapkan oleh instansi memperoleh nilai rata-rata 3,10 dengan kriteria jawaban cukup baik, ini dikarenakan masih ada pegawai yang tidak peduli terhadap peraturan perundang-undangan yang telah ditetapkan oleh instansi. Kemudian indikator hubungan kerjasama dengan pimpinan memperoleh nilai rata-rata 3,17 dengan kriteria jawaban cukup baik, hal ini adanya pegawai yang kurang berinteraksi dengan pimpinan.

Pada Indikator hubungan kerja sama dengan sesama pegawai lainnya memperoleh nilai rata-rata 3,05 dengan kriteria jawaban cukup baik, hal ini pegawai masih sering terjadi kesalahan dalam memahami komunikasi asesama antara pegaawai. Indikator Kemampuan pimpinan dalam memotivasi bawahannya memperoleh nilai rata-rata 3,17 dengan kriteria jawaban cukup baik, ini dikarenakan pimpinan kurang memberikan motivasi kepada bawahan. Kemudian Indikator kemampuan pimpinan dalam mengarahkan seluruh bawahannya memperoleh nilai rata-rata 3,37 dengan 
kriteria cukup baik, hal ini pimpinan kuran dapat menghendel bawahannya.

Dari total jawaban responden mengenai dimensi prestasi kerja dan perilaku kerja mendapat nilai rata-rata sebesar 3,12 dengan kriteria jawaban cukup baik. Kemudian nilai rata-rata tertinggi 3,82 dengan kriteria jawaban baik untuk dimensi sasaran kerja pegawai pada indikator kemampuan dalam mengelolah biaya. Sedangkan nilai rata-rata terendah sebesar 3,05 dengan kriteria jawaban cukup baik untuk dimensi sasaran kerja pegawai pada indikator tingkat penetapan target kerja.

\section{b. Deskriptif Kuantitatif}

\section{1) Analisa Regresi Linear}

\section{a) Pengaruh Komitmen Terhadap Disiplin Kerja}

Analisis regresi linear sederhana dalam penelitian ini digunakan untuk mengetahui pengaruh antara komitmen terhadap disiplin kerja. Dengan menggunakan program SPSS versi 20 , maka diperoleh hasil pengujian sebagai berikut:

Tabel 3

Hasil Uji Regresi Linear Sederhana

\begin{tabular}{|rr|r|r|r|}
\hline \multirow{2}{*}{ Model } & \multicolumn{2}{|c|}{$\begin{array}{l}\text { Unstandardized } \\
\text { Coefficients }\end{array}$} & $\begin{array}{c}\text { Standardized } \\
\text { Coefficients }\end{array}$ \\
\cline { 3 - 5 } & & \multicolumn{1}{|c|}{$\boldsymbol{B}$} & Std. Error & \multicolumn{1}{c|}{ Beta } \\
\hline 1 & (Constant) & $\mathbf{3 6 , 9}$ & 11,393 & \\
& & $\mathbf{8}$ & & \\
& Komitmen & $\mathbf{1 , 3 6}$ &, 239 &, 680 \\
\hline
\end{tabular}

a. Dependent Variable: Disiplin_Kerja

Sumber: hasil pengolahan data dengan SPSS Versi 20 (2018)

Berdasarkan hasil pengolahan data pada tabel 3 di atas dapat diperoleh persamaan regresi sebagai berikut: $\mathrm{Y}_{(\mathrm{Z})}=$ $36,985+1,365 \mathrm{X}$, artinya terdapat pengaruh positif antara komitmen terhadap disiplin kerja pada kantor Kecamatan Siantar.

b) Pengaruh Disiplin Kerja terhadap Kinerja Pegawai

Analisis regresi linear sederhana dalam penelitian ini digunakan untuk mengetahui pengaruh antara disipli kerja terhadap kinerja pegawai. Dengan menggunakan program SPSS versi 21, maka diperoleh hasil pengujian sebagai berikut:
Tabel 4

Hasil Uji Regresi Linear Sederhana

\begin{tabular}{|c|c|c|c|c|}
\hline & \multirow{2}{*}{ Model } & \multicolumn{2}{|c|}{$\begin{array}{c}\text { Unstandardized } \\
\text { Coefficients }\end{array}$} & \multirow{2}{*}{$\begin{array}{c}\begin{array}{r}\text { Standardized } \\
\text { Coefficients }\end{array} \\
\text { Beta }\end{array}$} \\
\hline & & $B$ & $\begin{array}{l}\text { Std. } \\
\text { Error }\end{array}$ & \\
\hline \multirow[t]{2}{*}{1} & (Constant) & 9,551 & 7,342 & \\
\hline & $\begin{array}{l}\text { Disiplin } \\
\text { Kerja }\end{array}$ &, 520 & ,072 & ,762 \\
\hline
\end{tabular}

a. Dependent Variable: Kinerja Pegawai

Sumber: hasil pengolahan data dengan SPSS Versi 20 (2018)

Berdasarkan hasil pengolahan data pada tabel 4 di atas dapat diperoleh persamaan regresi sebagai berikut: $\hat{Y}=$ $9,551+0,520 X_{(Z)}$ artinya terdapat pengaruh positif antara disiplin kerja terhadap komitmen pada kantor Kecamatan Siantar Kab. Simalungun.

2) Koefisien Korelasi dan Koefisien Determinasi

a) Hubungan Komitmen dengan Disiplin Kerja

Pada tahap ini akan dihitung korelasi berupa derajat atau kedalaman hubungan fungsional yang menjelaskan hubungan antar perubahan, disebut dengan koefisien yang disimbolkan dengan r. Pada pengujian ini dihitung hubungan variabel independent $(X)$ terhadap variabel mediasi (Z). Untuk mengukur seberapa besar variabel $\mathrm{X}$ menjelaskan variabel $\mathrm{Z}$ maka digunakan koefisien determinasi (KD). Berikut ini adalah hasil uji koefisien korelasi dan koefisien determinasi antara variabel komitmen (X) dengan variabel disipli kerja (Z). Dengan menggunakan bantuan program SPSS versi 20, didapatkan hasil perhitungan koefisien korelasi sebagai berikut:

Tabel 5

Analisis Koefisien Korelasi dan Koefisien Determinasi

\begin{tabular}{|c|c|c|c|c|}
\hline Model & $\boldsymbol{R}$ & $\begin{array}{c}\boldsymbol{R} \\
\text { Squa } \\
\text { re }\end{array}$ & $\begin{array}{c}\text { Adjuste } \\
\mathbf{d} \boldsymbol{R} \\
\text { Square }\end{array}$ & $\begin{array}{c}\text { Std. Error of } \\
\text { the Estimate }\end{array}$ \\
\hline 1 & $\mathbf{6 8 0}^{\mathrm{a}}$ & $\mathbf{4 6 3}$ &, 448 & 7,695 \\
\hline
\end{tabular}

a. Predictors: (Constant), Komitmen

b. Dependent Variable: Disiplin_Kerja

Sumber: hasil pengolahan data dengan SPSS versi 20 (2018)

Dari tabel 5 di atas diperoleh korelasi nilai $r=0,680$ artinya terdapat 
hubungan kuat dan positif antara komitmen dengan disiplin kerja pada Kantor Kecamatan Siantar Kab. Simalungun, sesuai dengan sesuai dengan kriteria korelasi pada tabel 3.4.

Diperoleh nilai koefisien determinasi (KD) 0,463 artinya tinggi rendahnya disiplin kerja (Z) pada Kantor Kecamatan Siantar Kab. Simalungun sebesar 46,3\% dapat dijelaskan oleh Komitmen (X), sedangkan sisanya $53,7 \%$ dijelaskan oleh faktor-faktor lain yang tidak dibahas dalam penelitian ini.

\section{b) Hubungan Disiplin Kerja dengan Kinerja Pegawai}

Pada tahap ini akan dihitung korelasi berupa derajat atau kedalaman hubungan fungsional yang menjelaskan hubungan antar perubahan, disebut dengan koefisien yang disimbolkan dengan r. Pada pengujian ini dihitung hubungan variabel mediasi (Z) terhadap variabel dependent (Y). Untuk mengukur seberapa besar variabel $\mathrm{Z}$ menjelaskan variabel $\mathrm{Y}$ maka digunakan koefisien determinasi (KD). Berikut ini adalah hasil uji koefisien korelasi dan koefisien determinasi antara variabel keputusan pembelian ( $\mathrm{Z}$ ) dengan variabel kepuasan konsumen (Y). Dengan menggunakan bantuan program SPSS versi 21, didapatkan hasil perhitungan koefisien korelasi sebagai berikut:

Tabel 6

Analisis Koefisien Korelasi dan Koefisien Determinasi

\begin{tabular}{|l|r|r|r|r|}
\hline $\begin{array}{l}\text { Mo } \\
\text { del }\end{array}$ & $\boldsymbol{R}$ & $\begin{array}{c}\boldsymbol{R} \\
\text { Square }\end{array}$ & $\begin{array}{c}\text { Adjusted } \\
\boldsymbol{R} \text { Square }\end{array}$ & $\begin{array}{c}\text { Std. Error of } \\
\text { the Estimate }\end{array}$ \\
\hline 1 & $\begin{array}{r}\mathbf{7 6 2} \\
\mathrm{a}\end{array}$ & $\mathbf{5 8 0}$ &, 569 & 4,645 \\
\hline
\end{tabular}

a. Predictors: (Constant),

Disiplin_Kerja

b. Dependent Variable:

KinerjaPegawai

Sumber: hasil pengolahan data dengan SPSS versi 20 (2018)

Dari tabel 6 di atas diperoleh korelasi nilai $r=0,762$ artinya terdapat hubungan kuat dan positif antara disipli kerja dengan kinerja pegawai pada Kantor Kecamatan Siantar Kab. Simalungun, sesuai dengan kriteria korelasi.
Diperoleh nilai koefisien determinasi (KD) 0,580 artinya tinggi rendah kinerja pegawai pada Kantor Kecamatan Siantar Kab. Simalungun sebesar 58\% dapat dijelaskan oleh disipli Kerja, sedangkan sisanya $42 \%$ dijelaskan oleh faktor-faktor lain yang tidak dibahas dalam penelitian ini.

3) Pengujian Hipotesis

a) Hipotesis 1: Pengaruh Komitmen Terhadap Disiplin Kerja

Pengujian ini dilakukan secara parsial yaitu dilakukan untuk menentukan diterimanya atau ditolaknya hipotesis, pengujian hipotesis dilakukan untuk mengetahui apakah variabel motivasi dan komitmen karyawan yang di uji berpengaruh terhadap kinerja karyawan. Jika $t_{\text {hitung }}>\mathrm{t}_{\text {tabel }}$ atau signifikansi $\leq 0,05$ maka $\mathrm{H}_{0}$ ditolak. Untuk menguji kebenarannya maka dilakukan pengujian hipotesis dengan menggunakan program aplikasi SPSS versi 20.

Tabel 7

Hasil Uji P arsial (Uji t)

\begin{tabular}{|ll|r|r|}
\hline \multicolumn{1}{|c|}{ Model } & \multicolumn{1}{c|}{$\boldsymbol{T}$} & \multicolumn{1}{c|}{ Sig. } \\
\hline 1 & (Constant) & 3,246 &, 002 \\
& Komitmen & $\mathbf{5 , 7 1 9}$ & $\mathbf{, 0 0 0}$ \\
\hline
\end{tabular}

a. Dependent Variable: Disiplin Kerja

Sumber: hasil pengolahan kuesioner menggunakan SPSS versi 20 (2018).

Berdasarkan tabel 7 di atas, diperoleh nilai $t_{\text {hitung }}$ pada variabel $X$ (Komitmen) sebesar 5,719 > $\mathrm{t}_{\text {tabel }}$ dengan $\mathrm{df}=\mathrm{n}-2$ (40$2=38$ ) sebesar 2,024 atau taraf signifikan $0,000<\alpha \quad 0,05$, maka $\mathrm{H}_{1}$ diterima, artinya komitmen berpengaruh positif dan signifikan terhadap disiplin kerja pada Kantor Kecamatan Siantar Kab. Simalungun.

b) Hipotesis 2: Pengaruh Disiplin Kerja Terhadap Kinerja Pegawai

Pengujian ini dilakukan secara parsial yaitu dilakukan untuk menentukan diterimanya atau ditolaknya hipotesis, pengujian hipotesis dilakukan untuk mengetahui apakah variabel motivasi dan komitmen karyawan yang di uji berpengaruh terhadap kinerja karyawan. Jika $t_{\text {hitung }}>\mathrm{t}_{\text {tabel }}$ atau signifikansi $\leq 0,05$ 
maka $\mathrm{H}_{0}$ ditolak. Untuk menguji kebenarannya maka dilakukan pengujian hipotesis dengan menggunakan program aplikasi SPSS versi 20.

Tabel 8

Hasil Uji Parsial (Uji t)

\begin{tabular}{|ll|c|rc|}
\hline & & & \multicolumn{2}{|c|}{ Sig. } \\
& Model & $\boldsymbol{t}$ & & \\
& & & \\
\hline 1 & (Constant) & 1,301 & &, 201 \\
& Disiplin Kerja & $\mathbf{7 , 2 4 5}$ & & $\mathbf{0 0 0}$ \\
\hline
\end{tabular}

a. Dependent Variable: Kinerja Pegawai

Sumber: hasil pengolahan kuesioner menggunakan SPSS versi 20 (2018).

Berdasarkan tabel 8 di atas, diperoleh nilai $t_{\text {hitung pada variabel } Z}$ (disiplin kerja) sebesar 7,245 $>t_{\text {tabel }}$ dengan df = n-2 $(40-2=38)$ sebesar 2,024 atau taraf signifikan $0,000<\alpha 0,05$, maka $\mathrm{H}_{2}$ diterima, artinya disipli kerja berpengaruh positif dan signifikan terhadap kinerja pegawai pada Kantor Kecamatan Siantar Kab. Simalungun.

\section{KESIMPULAN DAN SARAN \\ 1. Kesimpulan}

a. Hasil analisis deskriptif tentang Komitmen diperoleh rata-rat jawaban keseluruhannya sebesar 3,16 dengan kareteria jawaban cukup baik. Kemudian nilai rata-rata tertinggi sebesar 3,37 dengan kriteria jawaban baik pada dimensi komitmen afektif dengan indikator kebanggaan pegawai terhadap organisasi. Sedangkan nilai rata-rata terendah sebesar 2,87 denga kriteria cukup baik pada dimensi komitmen normatif dengan indikator rasa bersalah pegawai ketika meninggalka instansi.

b. Hasil analisis deskriptif kualitatif tentang disiplin kerja diperoleh rata-rata jawaban keseluruhan nilai rata-rata 3,27 dengan kriteria cukup baik. Nilai ratarata disiplin kerja tertinggi adalah 3,87 dengan kriteria baik untuk dimensi menjalankan kewajiban pada indikator usaha pegawai untuk mencapai sasaran kerja pegawai. Nilai rata-rata terendah adalah 2,30 dengan kriteria tidak baik untuk dimensi menjalankan kewajiban pada indikator dalam mengucapkan sumpah saat menjadi PNS.

c. Hasil analisis deskriptif kuantitatif tentang kinerja pegawai diperoleh nilai rata-rata jawaban keseluruhan sebesar 3,12 dengan kriteria jawaban cukup baik. Kemudian nilai rata-rata tertinggi 3,82 dengan kriteria jawaban baik untuk dimensi sasaran kerja pegawai pada indikator kemampuan dalam mengelolah biaya. Sedangkan nilai rata-rata terendah sebesar 3,05 dengan kriteria jawaban cukup baik untuk dimensi sasaran kerja pegawai pada indikator tingkat penetapan target kerja.

d. Komitmen (X) memiliki pengaruh yang positif terhadap disiplin kerja (Z), pada Kantor Kecamatan siantar Kab. Simalungun. Disiplin kerja (Z) memiliki pengaruh yang positif terhadap kinerja pegawai (Y) pada Kantor Kecamatan Siantar Kab. Simalungun.

e. Komitmen (X) memiliki hubungan yang kuat dan positif dengan disiplin kerja (Z) pada Kantor Kecamatan Siantar Kab. Simalungun. Disiplin kerja (Z) memiliki hubungan yang sangat tinggi dengan kinerja pegawai (Y) pada Kantor Kecamatan Sianta Kab. Simalungun.

f. Komitmen berpengaruh positif dan signifikan terhadap disiplin kerja pada Kantor Kecamatan Siantar Kab. Simalungun.

g. Disiplin keraja berpengaruh positif dan signifikan terhadap kinerja pegawai pada Kantor Kecamatan Siantar Kab. Simalungun.

\section{Saran}

a. Untuk meningkatkan komitmen pada Kantor Kecamatan Siantar Kab. Simalungun yang efektif dan efisien, hendaknya pegawai lebih meningkatkan semangat kerja sehingga terjalin komitmen yang kuat dengan instansi, serta pemimpin memberikan kepercayaan kepada pegawai dan memotivasi pegawai sehingga pegawai makin merasa terikat dan nyaman bekerja didalam instansi dan tercipta komitmen yang kuat dari diri pegawai, 
dan kinerja pegawai semakin meningkat.

b. Untuk meningkatkan disiplin kerja pegawai pada Kantor Kecamatan siantar Kab. Simalungun, pegawai harus lebih sadar atas sumpah yang telah diucapkan padasaat pengankatan PNS untuk dilaksanakan dan sijalankan agar asilnya lebih baik lagi dan selanjutnya pimpinan ada baiknya jika bersikap tegas terhadap pegawai yang melanggar peraturan kedinasan baik itu tertulis atau lisan, dan tidak ada salahnya jika pimpinan memberikan bonus atau penghargaan untuk pegawai yang menjalankan kewajiban dan menjauhi larangan dengan sungguhsungguh.

c. Untuk meningkatkan kinerja pegawai pada Kantor Kecamatan Siantar Kab. Simalungun, instansi sebaiknya mengoptimalkan kinerja pegawai, pegawai diharapkan memiliki catatan berupa nota atau agenda kerja agar dapat menjalankan target kerja dari organisasi, selain itu pimpinan harus memberikan semangat kepada para pegawai agar dapat bekerja dengan prosedur dan norma-norma yang ada di instansi agar tujuan perusahaan dapat tercapai dengan baik.

d. Sehubungan dengan keterbatasanketerbatasan yang ada pada penulis, penelitian ini masih terdapat kelemahan-kelemahan dan belum dapat mengungkap seluruh variabel yang dapat mempengaruhi kinerja pegawai pada Kantor Kecamatan Siantar Kab. Simalungun, sebagian bahan masukan untuk penelitian selanjutnya, perlu memperbanyak variabel penelitian seperti budaya organisasi, kompensasi, lingkungan kerja, prestasi kerja, kepuasan kerja dan variabel lain yang tidak diteliti dalam penelitian ini.

E. DAFTAR PUSTAKA

Daft, Richard L. 2002. Manajemen, Jilid 1, edisi kelima. Jakarta: Erlangga.

Dessler, Gary. 2006. Manajemen Sumber Daya Manusia. Jakarta : Indeks.

Handoko, T. Hani. 2003. Manajemen. edisi kedua. Yogyakarta: BPFE.
Mathis, Robert L. Dan John H. Jackson, 2006. Human Resources

Management. Jakarta : Erlangga.

Penggabean, Mutiara S. 2004, Manajemen

Sumber Daya Manusia. Bogor : Ghalia Indonesia.

Peraturan Pemerintah RI Nomor 53 Tahun 2010 Tentang Disiplin Pegawai Negeri Sipil.

Peraturan Pemerintah Nomor 46 Tahun 2011 Tentang Penilaian Prestasi Kerja Pegawai Negeri Sipil.

Rivai, Veithzal, et. Al, 2009. Manajemen Sumber Daya Manusia untuk Perusahaan dari Teori ke Praktik. Edisi III. Jakarta: PT Raja Grafindo Persada.

Robbins, Stephen P. dan Mary Coulter. 2010. Manajemen. Edisi kesepuluh. Jilid 1. Jakarta: Erlangga.

Sutrisno, Edy. 2010. Budaya Organisasi. Cetakan 1 Edisi pertama. Jakarta: Kencana Prenada Media Group. 